Danger signals: the number of US labs that can handle deadly pathogens is rising.

that ought to be classified, but those ought to be minimal. Otherwise you start generating suspicions and, frankly, generating excuses for other countries."

The department says that classification is necessary to prevent other nations from obtaining information about US weak points. ${ }^{\alpha}$ Providing a secure environment for the handling of sensitive information in this way makes sense, and will not allow our enemies to gain the advantage should vulnerabilities be revealed," says Christopher Kelly, a spokesman for the department.

Critics are also worried that the Department of Homeland Security could attempt to classify another project it has in the works: a \$450-million complex of highbiosecurity labs and testing grounds called the National Bio and Agro-Defense Facility. The department is holding a nationwide competition to determine where the lab will be located; 12 sites remain in the running. Kelly says the department has no plans to classify the complex in question. But one site that has made the shortlist is the Lawrence Livermore National Laboratory in California - which is already a classified facility.

${ }^{\alpha}$ How will the United States assure the rest of the world that the research is completely defensive if it's being conducted at a classified nuclear-weapons laboratory?" asks Marylia Kelley, executive director of TriValley CAREs, a Livermore-based group that monitors the national laboratory.

NBACC and the bio-agro facility are just part of a recent boom in biodefence spending in the United States. The federal government has spent $\$ 36$ billion to combat bioterrorism since the terrorist attacks of 11 September 2001, according to an analysis by the Center for Arms Control and Non-proliferation. Three additional biosafety level 4 labs are in the works, including one at Boston University in Massachusetts that has been heavily protested. Fourteen new biosecurity level 2 and 3 labs are also planned.

Pearson argues that the country should spend more on working to prevent bioterrorism in the first place, by strengthening the United Nations' biological and chemical weapons conventions, and improving supervision of its own research. "It wouldn't take much money to strengthen prevention, he says, "and it would do a lot more to keep us safe."

Erika Check

\title{
Plan to pool bird-flu data takes off
}

\section{A bid by leading researchers to bring into the open data on bird fluthat were previously kept behind closed doors has met with cautious optimism from observers.}

Some 70 avian-flu scientists from all corners of the globe have signed up to the Global Initiative on Sharing Avian Influenza Data (GISAID). A letter outlining the agreement was publis hed online last week in Nature and appears in this week's issue (see page 981).

The move aims to resolve issues that have seen some countries and organizations come underfire for hoarding genetic information about avian flu strains. The reasons for their reluctance to share are varied: some, for example, fear that others might use the data without properly crediting the researchers involved. And there were concerns over whether countries worsthit by bird flu would benefit from the drugs and vaccines developed from the sequences they provide.

Precise details of the GISAID agreement are still being thrashedout. But the idea is that participants will place genetic data into secure sections of existing online databases as soonas possible after producing and analysing them.

Peter Palese, who studies flu

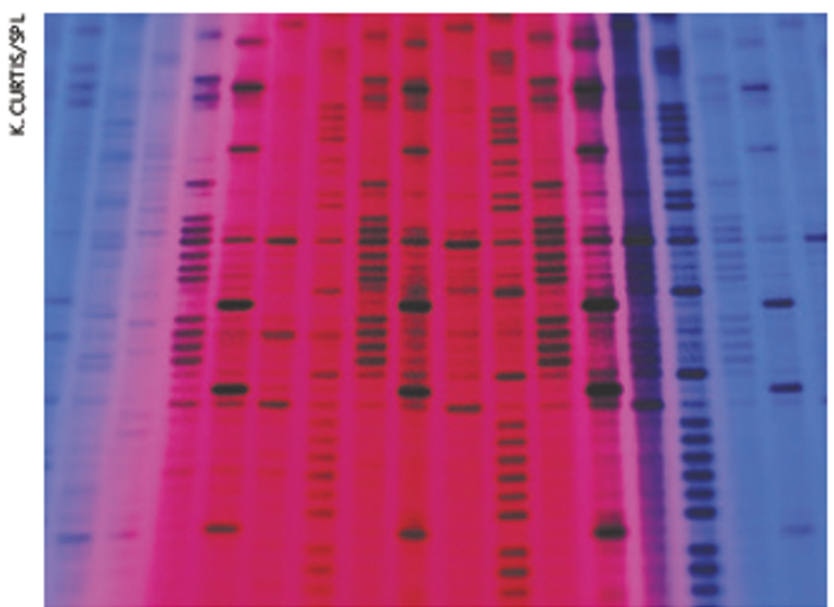

Lining up: access to DNA sequence data is vital for fighting bird flu. who have signed up to GISAID, but the information will become open to the public no more than six months after it is deposited.

GISAID members have also agreed to collaborate with, and appropriately credit, all relevant researchers in any resulting publications and intellectuar-property agreements.

Clinical and epidemiological data are included in the agreement. The hope is that researchers will be able to compare new strains against others quickly, for example to track whether a virus is acquiring mutations or becoming resistant to drugs.

Untilnow, access to many genetic sequences has been restricted to a global network of flu labs associated with the World Health Organization (WHO). Dick Thompson, WHO spokesman in Geneva, says that the organization supports the sharing of sequence data. Henotes that the WHO has sometimes been portrayed as wanting to keep data secret butsays that is not the case. "Sometimes countries have legitimate reservations and we have to work with that," he says. JohnSulston, of the Wellcome Trust Sanger Institute in Cambridge, UK, says that he supports GISAID as a compromise. Buthe adds that because bird flu is spreading around the globe so fast, "I still think it's a good idea to release data immediately."

Butvirologistllaria Capua at the Experimental Animal Healthcare Institute in Padua, Italy, whocampaigned for the initiative with Hollywood media adviser Peter Bogner, says she is very happy with the result She adds that the framework could be used for other emerging infectious diseases. "If a new SARS knocks on our door, we have a system in place." Helen Pearson 